\title{
Lymphocyte Count
}

National Cancer Institute

\section{Source}

National Cancer Institute. Lymphocyte Count. NCI Thesaurus. Code C51949.

The determination of the number of lymphocytes in a blood sample. 